\title{
Perception Analysis About Public Street Lighting In The Kota Kupang Nusa Tenggara Timur Province Indonesia
}

\author{
Jefirstson Richset Riwukore1)*, Yohanes Susanto'), Fellyanus Habaora3), Hilda \\ Manafe ${ }^{4}$ \\ 1)Study Program of Management Science, Post Graduate, University of Indo Global Mandiri, \\ Indonesia \\ 2) Study Program of Economic Science, Economy Faculty, Bina Insan Lubuklinggau \\ University, Indonesia \\ 3)Study Program of Animal Production and Technology, Post Graduate, Bogor Agricultural \\ University, Indonesia \\ 4) Researcher Council at Yayasan Jeriko Center Kupang, Indonesia
}

Received: 2020 July 13; Accepted: 2020 December 15; Published: 2021 January 31

\begin{abstract}
One of the cities in Indonesia that still performs the city arrangement is Kota Kupang in Nusa Tenggara Timur province. Several of criminal incidents and other crime allegedly occurred in areas that were still dark and there were no public street lighting. Therefore, a study has been carried out on the benefits of public street lighting in supporting population activities in Kota Kupang for six months, starting from January to June 2018. Determination sampling of respondents using purposive sampling technique. Based on this technique, then respondents in this study were 51 respondents scattered in each village at least 1 person. The data used in the research are primary and secondary data. The data obtained were then analyzed descriptively. The results of the research indicate that the implementation of public street lighting programs until 2017 has not given the Kota Kupang Government partisanship to the needs of population regarding public street lighting for daily activities.

Keywords: Human Perception; Public Street Lighting; Kota Kupang.
\end{abstract}

How to Cite: Riwukore, J.R., Susanto, Y., Habaora, F. \& Manafe, H. (2020). Perception Analysis About Public Street Lighting In The Kota Kupang Nusa Tenggara Timur Province Indonesia. PERSPEKTIF, 6 (2): 106-111

*Corresponding author:

ISSN 2085-0328 (Print)

E-mail: $\underline{\text { habaorafhomas@gmail.com }}$ ISSN 2541-5913 (online) 


\section{INTRODUCTION}

Public Street Lighting (PSL) is a lighting facility that helps residents carry out their economic and social activities at night, improving levels of security and order, beautify the atmosphere of the city, and the increasing attractiveness of a region so it develops quickly. To achieve this impact, then the PSL system must be reliable with the following criteria: (1) low energy so reducing electricity demand during peak loads and at the same time reduce emissions produced by PSL; (2) have light intensity which is in accordance with the designation of the road; (3) glare control, uniformity and light distribution are good so that it does not cause glare that can disrupt road users' comfort. This will form a unified public street lighting system, that is part of the complement of road that is installed on the left and/or right of the road or in the middle of the road that is used to illuminate the road (Al Irsyad, 2010; Mansur, 2015; Prihapso, et al., 2018).

One of the cities in Indonesia that is still perform the city arrangement is Kota Kupang in Nusa Tenggara Timur province. Several of criminal incidents and other crime allegedly occurred in areas that were still dark and there were no public street lighting. This can affect the condition of the community to be uncomfortable in doing activities at night such as fear go home from work at night, stunted night economic creativity (selling culinary, traveling coffee shops, etc.), and can cause vulnerability such as accidents and other crime. Therefore, it is necessary to conduct a research on the benefits of public street lighting in supporting residents activities in Kota Kupang. The results of this research are expected to be a contribution to policy making in the Kota Kupang Government. This research is in accordance with the instructions of SNI (2008) which states that public street lights are one of the needs of the community, become the obligation and responsibility of the regional/city government as a form of service to the community. Then from provincial roads to neighborhood roads demand road equipment along with the density of road user activity (Effendi \& Suryana, 2013; Effendi, et al.,
2018). One of the road equipment needed is Public Street Lighting.

\section{RESEARCH METHODS}

This research was conducted for 6 (six) months, starting from January to June 2018 in Kota Kupang. Determination of sampling (respondents) using purposive sampling technique, namely a method of sampling based on certain considerations or goals, and based on certain characteristics or traits that have been known before. Purposive sampling is used to achieve certain goals based on certain considerations. Based on this technique, the respondents in this study were taken randomly based on the distribution of urban village (in Indonesia: kelurahan) in Kota Kupang. Kupang City has 51 kelurahan which are distributed in 6 sub-districts. Thus the total sampling respondents is 51 people who are scattered in each kelurahan at least 1 person. This technique, according to Sugiyono (2001), is easier to do because consideration of the population is too much or the range is too broad so that it does not allow data to be collected from the entire population; limited power, time, and cost; and the assumption that the entire population is uniform so that it can be represented by a sample. The data used in the study are primary data and secondary data. Primary data obtained by interviewing techniques using questionnaires, and secondary data obtained by documentation techniques obtained from browsing on the internet, Kota Kupang statistical report, scientific article, and other documents relevant to this research. The data obtained were then analyzed descriptively.

\section{RESULTS AND DISCUSSION Profile of research respondents}

Gender of respondents consisted of two, namely male and female. Based on gender, the respondents were dominated by male 47 people or $92,16 \%$. Profile of respondents based on gender can be seen in Table 1.1.

Tabel 1. Profile of respondents based on gender 


\begin{tabular}{llll}
\hline No. Gender & $\begin{array}{l}\text { Total } \\
\text { Respondents } \\
\text { (people) }\end{array}$ & $\begin{array}{l}\text { of } \\
\text { Percentage } \\
(\%)\end{array}$ \\
\hline$(1)$ & $(2)$ & $(3)$ & $(4)$ \\
\hline 1 & Male & 47 & 92,16 \\
2 & Female & 4 & 7,84 \\
\hline & Total & $\mathbf{5 1}$ & $\mathbf{1 0 0 , 0 0}$ \\
\hline
\end{tabular}

Riwukore \& Habaora (2018) state that gender differences do not affect the strata of society, but more on outpouring of working hours and responsibilities between male and female. That is, gender differences in this research only show differences in the role of responsibilities in the family, where male tend to have greater responsibilities than female.

Age of respondent. Age is one of the factors that influence the mindset in determining kinds and patterns about an object. Aging only affects productivity but experience increases. Productive age between 15-55 years, but the age of $\leq 20$ years cannot be said to be productive because it is still of school age. Whereas the age of $\geq 56$ years is considered to be the level of productivity past the optimal point. Productivity affects the ability of one's mind so that productive age determines the taking of actions and decisions on an object (Riwukore \& Habaora, 2018). Profile of research respondents based on age can be seen in Table 2.

Tabel 2. Profil of respondents based on age

\begin{tabular}{llll}
\hline No. & $\begin{array}{l}\text { Age } \\
\text { Respondents } \\
\text { (years) }\end{array}$ & $\begin{array}{l}\text { Total of } \\
\text { Respondents } \\
\text { (people) }\end{array}$ & $\begin{array}{l}\text { Percentage } \\
(\%)\end{array}$ \\
\hline 11$)$ & $(2)$ & $(3)$ & $(4)$ \\
\hline 1 & $20-39$ & 13 & 25,49 \\
2 & $40-45$ & 9 & 17,65 \\
3 & $46-50$ & 12 & 23,53 \\
4 & $51-60$ & 12 & 23,53 \\
5 & $>60$ & 5 & 9,80 \\
\hline & Total & $\mathbf{5 1}$ & $\mathbf{1 0 0}, \mathbf{0 0}$ \\
\hline
\end{tabular}

Based on Table 2. shows that the profile of respondents is generally still in the productive age range, so respondents in this research can be categorized as good in exploring the perception of public street lighting in Kota Kupang. The majority of respondents were respondents aged 20-39 years as many as 13 people or $25,49 \%$, then respondents aged between $46-50$ years and 5160 years respectively $23,53 \%$, followed by respondents aged 40-45 years as many as 9 people or $17,65 \%$ and respondents aged $>60$ years were 5 people or 9,80 people.

Education. Based on the education level of the respondents, most of the respondents had educational qualifications at the level of high school/equivalent, namely as many as 21 people or $41,18 \%$. Then followed by respondents who had education at the junior high school level / equivalent of 12 people or $23,53 \%$, respondents who had tertiary education as many as 11 people or $21,57 \%$, and respondents who have education levels below the elementary school are 7 people or $13,73 \%$, as seen in Table 3. this following.

Based on Table 3. shows that respondent's education is considered to be quite good at the level of perception supporting this research. This is because an increase in one's knowledge, skills, productivity and income is also influenced by education. The level of education influences changes in mindset and the rate of absorption of innovation. Riwukore \& Habaora (2018) states that the level of education is positively correlated with the development of insights from someone. 
Table 3. Profil of respondents based on education

\begin{tabular}{|c|c|c|c|}
\hline No. & Education Level & $\begin{array}{l}\begin{array}{l}\text { Total of } \\
\text { Respondents } \\
\text { (people) }\end{array} \\
\end{array}$ & $\begin{array}{l}\text { Percentage } \\
\text { (\%) }\end{array}$ \\
\hline (1) & (2) & (3) & (4) \\
\hline 1 & $\begin{array}{l}\text { SElementary } \\
\text { School/equivalen }\end{array}$ & 7 & 13,73 \\
\hline 2 & $\begin{array}{lr}\text { Junior } & \text { High } \\
\text { School/equivalent }\end{array}$ & 12 & 23,53 \\
\hline 3 & $\begin{array}{lr}\text { Senior } & \text { High } \\
\text { School/equivalent }\end{array}$ & 21 & 41,18 \\
\hline \multirow[t]{2}{*}{4} & College & 11 & 21,57 \\
\hline & Total & 51 & 100,00 \\
\hline
\end{tabular}

1. Employment

The type of employment greatly influences a person's attitude. In general, the respondents in this research were mostly in the private sector, namely laborers, housewives, motorcycle taxis, traders, farmers, private sector, housebuilder, and students who also become the dominance in the table. For more details, see Table 4.

Table 4. Profil of responden based on employment

\begin{tabular}{|c|c|c|c|}
\hline No. & Employment & $\begin{array}{l}\text { Jumlah } \\
\text { Responden } \\
\text { (orang) } \\
\end{array}$ & $\begin{array}{l}\text { Persentase } \\
(\%)\end{array}$ \\
\hline$(1)$ & $(2)$ & (3) & (4) \\
\hline 1 & Laborers & 5 & 9,80 \\
\hline 2 & $\begin{array}{l}\text { Government } \\
\text { Lecturer }\end{array}$ & 4 & 7,84 \\
\hline 3 & Honorers & 3 & 5,88 \\
\hline 4 & Housewives & 2 & 3,92 \\
\hline 5 & $\begin{array}{l}\text { Motorcycle } \\
\text { Taxis }\end{array}$ & 5 & 9,80 \\
\hline 6 & Traders & 13 & 25,49 \\
\hline 7 & Farmers & 2 & 3,92 \\
\hline 8 & $\begin{array}{l}\text { Government } \\
\text { Employees }\end{array}$ & 6 & 11,76 \\
\hline 9 & Police & 2 & 3,92 \\
\hline 10 & Private & 6 & 11,76 \\
\hline 11 & Housebuilder & 1 & 1,96 \\
\hline \multirow[t]{2}{*}{12} & Colleger & 2 & 3,92 \\
\hline & Total & 51 & 100,00 \\
\hline
\end{tabular}

Data on Table 1.4. above shows that the distribution of respondents by type of employment has a percentage varying from $1,96 \%$ to $25,49 \%$. The distribution of this employment relates to activities carried out every day, and often passes through locations that can be categorized as difficult until the location is easily passed, from densely residents locations until less dense, etcetera. The activities that are undertaken form the experience of the objects it passes through so that it forms perceptions, such as the perception about public street lighting.

\section{Reasons for the Need for Public Street Lighting}

Public street lighting is a vital facility needed by modern society to improve traffic security, environmental security, orientation of area, and city accessories at night. Street lighting is also needed to support economic activity and mobility of the people at night 
(Effendi \& Suryana, 2013). Whereas SNI (2008) states that public street lighting is one of the community's needs so that the government is obliged and responsible in the procurement process as a form of service to its community. Therefore mandatory public street lighting is provided along provincial roads to neighborhood roads along with the density of road user activities, and one of the most needed road accommodation is public street lighting. Thus in general the reason for the need for public street lighting is for navigation, convenience, safety, economy, accessories, social, education and others. Data on the reasons for public street lighting needs in Kota Kupang can be seen in Table 2 .

Table 2. Reasons for the Need for Public Street Lighting

\begin{tabular}{|c|c|c|c|c|c|c|c|}
\hline \multirow[b]{2}{*}{$\begin{array}{l}\text { No } \\
\cdot\end{array}$} & \multirow[b]{2}{*}{$\begin{array}{l}\text { Variable } \\
\text { s }\end{array}$} & \multicolumn{2}{|c|}{$\begin{array}{l}\text { Reason for } \\
\text { need }\end{array}$} & \multicolumn{2}{|c|}{ Abstains } & \multicolumn{2}{|l|}{ Total } \\
\hline & & $\begin{array}{l}\text { Res } \\
\text { po } \\
\text { nd } \\
\text { ent }\end{array}$ & $\%$ & $\begin{array}{l}\text { Re } \\
\text { sp } \\
\text { on } \\
\text { de } \\
\text { nt }\end{array}$ & $\%$ & $\begin{array}{l}\text { Resp } \\
\text { onde } \\
\text { nt }\end{array}$ & $\%$ \\
\hline (1) & (2) & (3) & (4) & (5) & (6) & $\begin{array}{l}\text { (7) }=( \\
3)+(5 \\
)\end{array}$ & $\begin{array}{l}(8)=(4) \\
+(6)\end{array}$ \\
\hline 1 & $\begin{array}{l}\text { Navigatio } \\
\mathrm{n}\end{array}$ & 30 & 58,82 & 21 & 41,18 & 51 & 100,00 \\
\hline 2 & $\begin{array}{l}\text { Convenie } \\
\text { nce }\end{array}$ & 50 & 98,04 & 1 & 1,96 & 51 & 100,00 \\
\hline 3 & Safety & 49 & 96,08 & 2 & 3,92 & 51 & 100,00 \\
\hline 4 & Economy & 39 & 76,47 & 12 & 23,53 & 51 & 100,00 \\
\hline 5 & $\begin{array}{l}\text { Accessori } \\
\text { es }\end{array}$ & 19 & 37,25 & 32 & 62,75 & 51 & 100,00 \\
\hline 6 & Social & 14 & 27,45 & 37 & 72,55 & 51 & 100,00 \\
\hline 7 & $\begin{array}{l}\text { Educatio } \\
\mathrm{n}\end{array}$ & 17 & 33,33 & 34 & 66,67 & 51 & 100,00 \\
\hline
\end{tabular}

The function of public street lighting needs as navigation is to determine/monitor the movement of vehicles along the track. The term navigation itself is used to refer to kinematic based estimates of vehicle state (position, speed, and attitude) in real time as a reference to determine the movement of vehicles along the movement path (Widyantara, et al., 2015). Brain function and body move will coalesce when passing a track whether tightening the vehicle or slowing down the vehicle, or when passing the track on foot. This function is very integrated into the receptors of sensory vision and motor nerves. Perception that states the reason for the need for PSL as navigation as many as 30 respondents or $58,82 \%$. While as many as 21 respondents or $41,18 \%$ did not state the function of the PSL as navigation because they were accustomed to going through the road in carrying out their daily activities so that they knew the location that was often passed by them. Riwukore \& Habaora (2018) state that experience shapes the ability to make decisions about the use of an object, in this case it is very closely related to the ability to drive a vehicle or move the body to walk, slowly, and or be careful. Then Riwukore \& Habaora (2019ab) state that the habits that are carried out every day shape a person's motoric experience and thus influence the perception that this is not a need.

The function of street lighting as a giver of security has an meaning that one's perception of an object there is no sense of worry, feeling of fear, or other psychological abnormalities when carrying out an activity. The results showed that the perception of the reason for the need for public street lighting was due to convenience with a percentage equal to $98,04 \%$ or as many as 50 respondents. While 1 respondent or $1,96 \%$ of respondents stated abstention (does not mentioning). This shows that residents of Kota Kupang really need street lighting to provide convenience in their activities at night so as not to cause anxiety, fear, or other psychological disorders.

The function of public street lighting for safety means that street lights help in preventing accidents or other incidental effect that threaten a person's life. Based on this, 49 respondents or $96,08 \%$ of respondents stated 
that the reason for the need for street lighting was for safety. Data from Kota Kupang Police stated that the percentage of traffic accidents in Kota Kupang had increased at 2018 by 7,35\% (Pos Kupang, 2018). It is alleged that one of the causes of traffic accidents because of driving at night under the influence of alcohol and others without good lighting at night. Likewise the number of mugging in Kota Kupang began to increase due to the dark atmosphere of the road (Antara, 2018). The high percentage of street lighting needs is because the respondents' employments are generally in the private sector.

The function of public street lighting for the economy means that public street lights have an economic impact or an increase in income. The results of this study indicate that as many as 39 respondents or $76,47 \%$ of respondents stated that the reason for the need for public street lighting for the economy. This is related to the livelihoods of the respondents, where most of them are traders so that the more longer the time to sell goods at night, has the potential to increase income. The existence of public street lighting also has the potential to generate new business such as culinary business under street lighting. Highway lighting has an economic function, namely the distribution of goods (Limbong \& Kasim, 2014; Widodo, 2016).

Public street lighting has a function as a city-oriented cultural and artistic accessory, such as in PSL in parks, recreational locations, etc. The results of this study indicate that as many as 19 respondents or $37,25 \%$ of respondents stated that the reason for the need for public street lighting is accessories. While the remaining 32 people or $62,75 \%$ of respondents said they abstained. (Saputri \& Hidayah (2014) reported the function of accessories from public street lighting in Malioboro Yogyakarta increasingly adding to the value of cultural treasures because of the nighttime light from public street lighting funiture display full of culture and distinctive art that show Yogyakarta's residents character.

Public street lighting has urban social functions. The results of this research indicate that as many as 14 respondents or $27,45 \%$ of respondents stated that the reason for the need for public street lighting for social needs, and the remaining 37 respondents or $72,55 \%$ said they abstained. Winardi \& Nugroho (2007) state that the social function of public street lighting for the population is that interaction in living in a society is not limited by worry and fear. Community interaction can occur in stalls around the public street lighting area, or family visits that are not limited to fear when crossing the road illuminated by PLS.

Public street lighting has an educational function. The results showed that 17 respondents or $33,33 \%$ of respondents stated that the reason for the need for public street lighting for education, and the remaining 34 respondents or $66,67 \%$ of respondents said they abstained. The benefits of public street lighting in the function of education tend to be influenced by locations such as parks, youth children's hangout locations, and so on to gather and discuss science. In addition, public street lighting in the function of education is related to social functions, namely social interaction.

\section{Residents Perception of Public Street Lighting in Kota Kupang}

The results of the research on public perceptions of public street lighting in Kota Kupang in 2017 indicate that existing PSL have not shown the government's partiality to the residents (Table 3). The residents stated that they did not agree if the existing PSL was in accordance with their needs $(60,78 \%)$ and $31,37 \%$ stated that they agreed enough. Whereas only $7,84 \%$ stated that the existing PSL was in accordance with the needs of the residents. This may be due to the available PSL not yet supporting the morbidity (conveinance and safety) of the residents in carrying out daily activities. This can be seen from 76,47-98,04\% of the residents in Kota Kupang requires public street lighting to support economic activities and provide safety and conveinance in carrying out daily activities.

Kota Kupang Government is also considered not to pay attention to the needs of public street lighting in Kota Kupang because only $21,57 \%$ of the residents agreed. Whereas a number of $37,25 \%$ and $41,18 \%$ of the residents stated that they agreed and did not agree that the government had care to PSL as a residents need. This condition is influenced by the perception of the resident if the available PSL has not matched the needs of the resident because it has not given a sense of partisanship of the government towards the residents. 
Therefore, residents stated that the needs of PSL are very urgent with a percentage that

states that they agree at $94,12 \%$ and quite agree at $3,92 \%$.

Table 3. Residents Perception of Public Street Lighting in Kota Kupang

\begin{tabular}{llllll}
\hline \multirow{2}{*}{ No. } & & \multicolumn{3}{c}{ Vesidents Perception } \\
\cline { 3 - 6 } & & Agree & Enough & Disagree & Total \\
\hline$(1)$ & $(2)$ & $(3)$ & $(4)$ & $(5)$ & $(6)$ \\
\hline 1 & PSL has been as needed & 7,84 & 31,37 & 60,78 & 100,00 \\
2 & The government cares with PSL & 21,57 & 37,25 & 41,18 & 100,00 \\
3 & Location of PSL in a strategic place & 3,92 & 17,65 & 78,43 & 100,00 \\
4 & The needs of PSL are urgent & 94,12 & 3,92 & 1,96 & 100, oo \\
5 & The existing PSL helps with activities & 3,92 & 23,53 & 72,55 & 100, oo \\
6 & PSL is still difficult to reach isolated locations & 78,43 & 17,65 & 3,92 & 100,00 \\
7 & Public complaints were quickly responded & 1,96 & 23,53 & 74,51 & 100,00 \\
8 & Light from existing PSL, glare & 13,73 & 82,35 & 3,92 & 100,00 \\
\hline
\end{tabular}

The residents also considers that the existing PSL is still difficult to reach isolated locations, such as in suburban areas with a percentage of $78,43 \%$ agreeing, the remaining $17,65 \%$ and $3,92 \%$ of the residents declaring that they enough and disagree. Even the public complained about the management of public complaints related PSL dead, or PSL requests because the government was very slow in responding to these public complaints, of which $74,51 \%$ of the residents stated that Kota Kupang Government was very slow in responding to public complaints.

The residents still considers that the PSL that already exists or is installed by Kota Kupang Government has not provided support for daily activities because $72,55 \%$ of the residents disagrees if the existing PSL helps with their activities. Even existing PSL in terms of lighting have not provided users with a sense of comfort due to the glare of lighting. This is based on the percentage of amounting to $82,35 \%$ of the residents stating that they agree enough if the existing PSL is still glare. Road lighting is a measure of efficient traffic safety (Hompas \& Kindangen, 2018). Then (Patel, et al., 2014) state that measurement of luminous flux and poor visibility in street lighting causes accidents and enforcement of traffic needs to be done scientifically so that road users can utilize facilities within the framework, techniques and polite behavior and respect other fellow road users. The need for continuous analysis of roads related to accidents due to lighting can help users read the road situation at night.

\section{CONCULISON}

Public street lighting is one of the infrastructures that must be met to roads so that it can be used at night to support community activities. But the results of the research indicate that the implementation in 2017 public street lighting program has not provided partisanship from Kota Kupang Government to the needs of the resident for public street lighting in carrying out daily activities.

\section{BIBLIOGRAPHY}

Al Irsyad, M. I., (2010). Energy savings for DKI Jakarta public street lighting: survey, potential and economy. Jurnal Ketenagalistrikan dan Energi Terbarukan, $9(2), 89-98$.

Antara, (2018). Nekat jambret ponsel mahasiswimahasiswa di Kupang ditangkap polisi. [Online] Available at: http://www.inews.id/daerah/regional/neka t-jambret-ponsel-mahasiswi-mahasiswa-dikupang-ditangkap-polisi/360298 [Accessed 5 Januari 2019].

Effendi, A., Dewi, A. Y. \& Elvira, L., (2018). The opportunity to save energy in public street lighting in Padang Pariaman district in work area PT. PLN (Persero) Rayon Pariaman Feeder Kampung Dalam. Jurnal Teknik Elektro ITP, 7(1), pp. 51-60.

Effendi, B. A. \& Suryana, A., (2013). Evaluation of street lighting systems in Sungai Bahar subdistrict. Jurnal Teknik Elektro ITP, 2(2), pp. 86-94. 
Hompas, M. M. \& Kindangen, J. I., (2018). Street lighting and pedestrian at the Center Kota Manado. Jurnal Fraktal, 3(1), pp. 1-10.

Pos Kupang.,

(2018).

[Online]

Available

https://kupang.tribunnews.com/2018/12/1

3/meningkat-korban-meninggal-akibatkecelakaan-sepeda-motor-di-kupang

[Accessed 5 Januari 2019].

Limbong, D. B. \& Kasim, S. T., (2014). Technical and economical comparison of the use of public solar street lighting with conventional public street lighting. Jurnal Singuda Ensikom, 8(3), 146-151.

Mansur, (2015). The analysis on the electrical system on the public street lighting in the office area in Konawe Selatan. Dinamika: Jurnal Ilmiah Teknik Mesin, 7(1), 33-40.

Patel, M., Parmar, A., Patel, V. \& Patel, D. M., (2014). Road lighting as an accident counter measure. International of Civil Engineering and Technology, 5(12), 296-304.

Prihapso, Y., Farhania, W., Suryani, D. \& Nelfyeni, (2018). Led street light colorimetry measurement using arrayspectroradiometer. Jurnal Standarisasi, 20(1), 49-56.

Riwukore, J. R. \& Habaora, F., (2018). Sistem produksi sapi potong. Jogjakarta: Deepublish.

Riwukore, J. R. \& Habaora, F., (2019). Perception of farmers on the performance of extensionist in the pasture agroecosystem of Timor Tengah
Utara district. Asian Journal of Agricultural Extension, Economics, and Sociology, 29(2), 110.

Riwukore, J. R. \& Habaora, F., (2019). The local community perception towards pig farming in Kupang City East Nusa Tenggara Indonesia. Asian Journal of Science and Technology, 10(5), 9660-9664.

Saputri, D. S. \& Hidayah, R., (2014). Evaluasi street furniture lampu jalan di koridor kawasan Malioboro, Yogyakarta. Jurnal Inersia, 10(2), 154-162.

SNI, (2008). SNI Nomor 7391 tentang spesifikasi penerangan jalan di kawasan perkotaan. Jakarta: Badan Standarisasi Nasional (BSN).

Sugiyono, (2001). Metode penelitian. Bandung: Alfa Beta Press.

Widodo, A., (2016). Management study of optimization of public street lighting in Kota Semarang. Jurnal Teknik Sipil dan Perencanaan, 2(18), 87-96.

Widyantara, I. M. O., Warmayana, I. G. A. K. \& Linawati, (2015). Application of GPS Tracker technology to identify road traffic conditions. Jurnal Teknologi Elektro, 14(1), 31-35.

Winardi, B. \& Nugroho, A., (2007). Planning for public street lighting as an effort to improve the efficiency of electricity bills in Suruh Subdistrict, Semarang Regency, Salatiga UPI. Jurnal Teknik Elektro Transmisi, 9(2), 138144. 